\title{
Responsibility and ultimate ends in the age of the unforeseeable. On the current relevance of Max Weber's political ethics
}

\author{
Luigi Pellizzoni (University of Pisa)
}

Journal of Classical Sociology, 2018, DOI: 10.1177/1468795X18758232

\begin{abstract}
Ethic of responsibility and ethic of ultimate ends are most discussed Weberian concepts. The article reflects on their heuristic value in the present. A common interpretation claims that in a rationalized society the ethic of responsibility supplants or integrates the ethic of ultimate ends. The two ethics, however, fundamentally differ according to their relationship with the unforeseeable. Moreover, contrary to the idea of a relentless rationalization of society, the unforeseeable is today gaining relevance, even ceasing to be regarded as a problem. As a result, the ethic of ultimate ends expands its scope. The article dwells on major implications of this. The enduring relevance of Weber's conceptualization, it is concluded, lies in its independence from the historical conditions in which it was formulated.
\end{abstract}

Keywords: Ethic of responsibility, ethic of ultimate ends, foreseeability, innovation, rationalization, uncertainty, Weber

\section{Introduction}

Despite their occasional character, the conferences on science and politics as a profession, or vocation, enjoy a prominent position in Max Weber's production. They offer a synthesis and an accomplishment of key themes, from rationalization to science's avalutativity, from the polytheism of values to the nature of politics. Among the many aspects on which the debate has focused a major place is held by the conceptual couple that constitutes the core of the conference on politics: Verantwortungsethik and Gesinnungsethik. The first term has always been translated as 'ethic of responsibility', while the second raises well-known difficulties of translation. In English (similarly to other languages) one finds it rendered with 'intention', 'conviction' and 'ultimate ends'. In the following I will use the latter expression.

According to a recent review article, two tendencies can be detected in contemporary literature on Weber. One seeks to 'correct misunderstandings, clarify misconceptions and properly locate his work in the intellectual and social context within which he lived'; the other puts an emphasis on 'applying, 
adapting and using Weber's concepts and ideas for understanding the contemporary world' (Rosenberg, 2016: 297). The present paper belongs to the latter strand. Its aim is to show the enduring utility of the conceptual couple Weber developed in the conference. Such utility - this is my basic thesis - does not depend on the persistence of the world in which it was elaborated, but on its ability to show the distance that separates the present from that world. Said differently, the heuristic value of the concepts should be kept distinct from the epochal diagnosis and the contingent preoccupations underlying their formulation. Formulation which, of course, has also to be reconsidered - as Rosenberg remarks, by no means the 'applicative' approach to Weber can do without a proper understanding of his concepts and ideas.

I proceed in four steps. I focus first on an interpretation of Weber according to which, in a rationalized society, the ethic of responsibility supplants or integrates the ethic of ultimate ends. I do not contend this is the only reading existing, nor in the space available can I properly demonstrate it is the dominant one. This interpretation, in any case, is hardly marginal, being a frequent encounter in the Weberian literature. Second, I show how the two ethics fundamentally differ according to their relationship with the unforeseeable. Third, I reflect on how, contrary to the idea of a relentless rationalization of society, the unforeseeable is today gaining relevance in a variety of fields, with ensuing expanding scope of the ethic of ultimate ends. Fourth, I argue that in a growing number of cases the unforeseeable even ceases to be regarded as a problem, being instead conceived as an opportunity. This further expands the role of the ethic of ultimate ends.

As Rosenberg remarks, at the core of Weber's methodological stance lies the validity of concepts (that is, their capacity to shed light on the phenomena under scrutiny) rather than their connection with 'worldviews' (that is, encompassing accounts of modernity's character and destiny). Accordingly, the conclusion stresses that the enduring significance of Weber's conceptualization lies in its independence from the historical conditions in which it was formulated.

\section{The two ethics: a problematic relationship}

Let's read Weber's words:

All ethically oriented conduct may be guided by one of two fundamentally differing and irreconcilably opposed maxims: conduct can be oriented to an 'ethic of ultimate ends' or to an 'ethic of responsibility.' This is not to say that an ethic of ultimate ends is identical with irresponsibility, or that an ethic of responsibility is identical with unprincipled opportunism. Naturally nobody says that. However, there is an abysmal contrast between conduct that follows the maxim of an ethic of ultimate ends - that is, in religious terms, 'The Christian does rightly and leaves the results with the Lord' - and 
conduct that follows the maxim of an ethic of responsibility, in which case one has to give an account of the foreseeable results of one's action (Weber, 1946a: 120)

A few lines later Weber adds that those who follow an ethic of ultimate ends do not feel responsible for the negative consequences of their actions, because they are not interested in a particular outcome but in keeping alive the flame of pure intentions. Their deeds are 'quite irrational, judged in view of their possible success. They are acts that can and shall have only exemplary value'. On the contrary, those who act according to the ethic of responsibility 'take account of precisely the average deficiencies of people' (1946a: 121), hence they regard themselves as responsible for the undesired effects their action will produce, if these could have been foreseen.

The distinction seems clear enough. Yet, things soon get more complicated. Weber adds that no ethics in the world (so also an ethic of ultimate ends) can dodge the problem of the relationship between ends and means, that is, the extent to which the attainment of good ends justifies the use of ethically dubious or dangerous means. Later he claims that the two ethics 'are not absolute contrasts but rather supplements' (1946a: 127). As we have seen, however, Weber talks also of an 'abysmal contrast' between the two conduct orientations, adding that it is not possible to bring an ethic of ultimate ends and an ethic of responsibility under one roof or to decree ethically which end should justify which means' (1946a: 122). The two ethics, therefore, seem to be both reciprocally implied and incompatible. This has troubled commentators. A characteristic 'solution' of the apparent contradiction is however easily discernible in the literature. I'll provide a few examples.

For Wolfgang Schluchter, one of Weber's most prominent students, behind the oscillation between opposition and complementarity a fundamental divergence can be detected between the two ethical orientations (1979b: 87). Moreover, he argues, Weber's argument holds only if one reads it as a devaluation of the ethic of ultimate ends, imposed by the recognition that, in a rationalized society, political decision has 'to accept the restrictive conditions formulated by science' (1979b: 86). For Schluchter, therefore, the conference gives a decisive prominence to the ethic of responsibility. Apparently different but eventually analogous is the route taken by those who, rather than claiming the incompatibility of the two ethics, make a case for their harmonization. To this purpose the isomorphism between the couple Verantwortungsethik/Gesinnungsethik and the couple Zweckrationalität/Wertrationalität - a line of reasoning arguably inaugurated by Karl Löwith ([1932]1993) - is often brought to the fore. For example, Rogers Brubaker (1984: 108-9) holds that those who adopt an ethic of ultimate ends apply value-rationality, whereas the ethic of responsibility does not merely apply means-ends rationality but addresses the problem of the relationship between ends and consequences of action, hence how acceptable are such consequences compared with the importance of the ends; importance that can be decided only on the basis of value criteria. In other words, the ethic of responsibility integrates the two types of rationality: value-rationality serves to 
define the ends and weigh their relevance; instrumental rationality to specify, on such grounds, the means and the foreseeable consequences of action. Nicholas Gane (1997: 552) contests the idea of an integration of instrumental and value rationality. He maintains, however, that the ethic of responsibility is an ideal-type of Zweckrationalität, which precludes commitment to ultimate values yet is synthesised with the value-rationality of Gesinnungsethik. To my eyes, the difference between Brubaker's account of 'integration' and Gane's account of 'synthesis' is elusive. In both cases, anyway, the ethic of ultimate ends is subsumed to the ethic of responsibility, losing its key feature, namely the unconditional adhesion to a principle. Joshua Cherniss is most explicit in this regard: 'Purposive rationality can guide decisions about what ends to pursue, [...] recogniz[ing] potential conflicts between values and the need for trade-offs and choices between them' (2016: 712). Nick O'Donovan similarly contends that 'Weber's conception of responsibility does impose constraints on a leader's choice' (2011: 90, emphasis original). Thus, it is not values that set the parameters for responsibility, but the other way round. Isher-Paul Sahni (2001) also aligns with this view, claiming that the subordination of the ethic of ultimate ends to the ethic of responsibility consists in the fact that the ultimate end of the politician has to be the recognition of responsibility.

I could go on with other examples. To make it short, let's say that, for a number of scholars across a significant time span (look at the publication dates of citations), the ethic of responsibility has primacy over the ethic of ultimate ends, the latter being either supplanted or integrated (and defused) in the former. Of course, we are talking of modern society, where means-ends rationality has taken a growing role and where politics has become an autonomous sphere of meaning, related but not confused with others, including morals and science. Such relationship is precisely what is in question in the conference.

Weber's account, however, seems to preclude such an easy solution. About the ethic of ultimate ends, as we have seen, he holds the apparently aporetic claim that its application is irrational from the viewpoint of the possible consequences, yet not insensitive to these. About the ethic of responsibility, Weber is concerned with distinguishing it from 'power politics', that is, the use of power for the sake of it, where the lack of a cause is often 'identical with irresponsibility' (1946a: 116). The presence of a goal external to the mere exercise of power prevents the acceptance of any means or the avoidance of any foreseeable negative consequence. As a result, one will find oneself 'at some time in th[e] position [...] of saying "Here I stand; I can do no other"' (1946a: 127).

Thus, political ethics finds its space between power politics and fully irrational behaviour. 'The final result of political action often, no, even regularly, stands in a completely inadequate and often even paradoxical relation to its original meaning. This is fundamental to all history, a point not to be proved in detail here. But because of this fact, the serving of a cause must not be absent if action is to have inner strength' (1946a: 117). In this way, the 'ethical irrationality of the world' (1946a: 122), which 
Weber stresses in other occasions ${ }^{1}$, embroils with the epistemic limits of instrumental rationality, also underscored various times. ${ }^{2}$

Yet, if there is consideration of consequences in principled action and consideration of values in responsible behaviour, what is the purpose of a distinction that does not discriminate well even in the abstract? The answer has to consider that, in the text we are discussing, Weber dealt with the political profession, or vocation. Not, therefore, politics as a theory, but as a practice. Weber aimed to show how the political profession implies a daily confrontation with this discord; an awareness of the 'tragedy with which all action, but especially political action, is truly interwoven' (1946a: 117). The two concepts, therefore, describe an apory, not the way to resolve it. ${ }^{3}$

As we have seen, however, it is easy to detect in Weberian literature precisely this attempt: resolving the apory by giving primacy to the ethic of responsibility. This strategy reaches an extreme in the following argument. According to Weber, 'the proponent of an ethic of absolute ends [...] is a cosmicethical "rationalist"' (1946a: 122). In other words, this person believes in the rational order of existence, according to given principles. Then, it is claimed, this the one who applies a calculative rationality, rather than those who follow an ethic of responsibility. The latter, just because they acknowledge the ethical irrationality, hence the incalculability, of existence, are aware they have to hold on some ethical principle not further justifiable. In short, the actual ethic of ultimate ends is the ethic of responsibility (Satkunanandan, 2014).

It is doubtful that such stretching of the notion of 'calculation' is correct. For Weber calculation is synonymous with instrumental rationality. Action, he says, 'is instrumentally rational when the end, the means, and the secondary results are all rationally taken into account and weighed' (1978: 26), as with monetary calculation in economic action. This is precisely what the 'cosmic-ethical rationalist' does not do. The point is important for the argument I develop in the following section, yet counts here as additional evidence of the tendency to search for any possible argument in order to grant the ethic of responsibility primacy over the ethic of ultimate ends. Two are the main reasons for that, variedly stressed by Weber's commentators. The first concerns the context of the conference; the second the overall coherence of Weber's thought.

The conference on politics has an explicit polemic purpose. In the aftermath of the World War, in a dramatic moment for Germany and Europe, Weber aims to warn the young university students against the dangers of political extremism, be it marked by an excess of idealism or an excess of realism, which is often an inversion of the former. From this stems the hostility of the text for those who refuse responsibility by appealing to principles, be these the utopian pacifist or the syndicalist protesting against social injustice; a refusal that puts them on a par with the soulless realism of the bureaucrat who applies the rules, or the politician that aims at power for the sake of it. The pre-eminence of the ethic of responsibility seems also consistent with Weber's epochal diagnosis: rationalization as a relentless process thanks to the higher organizational efficiency and operational 
effectiveness of means-ends rationality, compared with any other logic of action. If he concludes The Protestant Ethic and the Spirit of Capitalism (Weber, 2001) with a note of caution, remarking that the 'iron cage' is not necessarily the final destination of modernity, modern political ethics can hardly disregard the availability of increasingly robust knowledge and means of intervention. The role of science in this process is especially stressed. I have already mentioned Schluchter, yet comparable arguments about the centrality of science for political action can be found in Brubaker, Gane and others (for example Scaff, 1989). Another example is O'Donovan (2011). He claims that the ethic of responsibility, before purposive rationality (which the bureaucrat and the power politician also apply), is a matter of responsibility-taking for actual outcomes - beyond foreseen ones yet within the limits of foreseeable ones, as clarified by scientific inquiry.

Underlying this view is a conventional understanding of science as the social institution presiding over the production of reliable knowledge, based on objective measurement and expressed in prediction. Such view is consistent with the liberal tradition, ${ }^{4}$ as synthesized in Aaron Wildavsky's (1979) wellknown expression, that 'science speaks truth to power'. Science, more precisely, is assumed to strengthen the efficacy of government action, depersonalizing decision and linking its legitimacy to the credibility of the observation of facts (Ezrahi, 1990). This assumption, however, has progressively narrowed its scope. Post-war narratives of a smooth matching between political demands and technical responses (Bush, 1945) have been superseded by the acknowledgment that political choice follows criteria of opportunity, beyond and before technical efficiency (Pellizzoni, 2009). More recently, the idea has gained momentum that politics and industry are entitled to directly set the lines of research, in so doing circumscribing from the outset the 'facts' to be observed. 5

Applying the Weberian categories to the present means tackling the way science works and relates with politics and business, as well as other institutional and cultural changes. In this regard, I contend, it means tackling first of all the way the unforeseeable affects behaviour in a variety of fields. To address this point we have to start with reflecting on the role the unforeseeable plays in the two ethics.

\section{The two ethics and the unforeseeable}

The ethic of responsibility applies to the foreseeable consequences of action, Weber says. What is known, therefore, is regarded as adequate to taking reliable decisions - taking 'risks' in the proper sense of making probability estimates. Those who follow an ethic of ultimate ends, instead, give their action an 'exemplary value'. What does this mean? It cannot be a strategy for inducing impulsive imitation, otherwise we would have on one side (agent) instrumental rationality, on the other (imitator) irrationality. Exemplarity, instead, corresponds to Weber's definition of value-rational action, as an action carried out 'for its own sake' in reply to "commands" or "demands" which, in the actor's opinion, are binding on him' (1978: 25). 'Exemplary prophets' like the Buddha, 'who, by his personal example, demonstrates to others the way to religious salvation' (1978: 447), are a case in 
point. And 'the more unconditionally the actor devotes himself to [a] value for its own sake, [...] the less is he influenced by consideration of the consequences of his action' (1978: 26) - hence, in the conference, the reference to the maxim 'The Christian does rightly and leaves the result with the Lord'. So, choosing an ethic of ultimate ends seems to entail complete disregard for consequences. Yet, for Weber, 'rationality' always means orientation to the control of the world through information processing (Schluchter, 1979a: 14). How, then, can exemplary action be regarded as rational, rather than affectual or traditional? How can one 'consistently plan [...] its detailed course' (Weber, 1978: 25) without falling into magic ritualism? The reply is: because the actor is a 'cosmic-ethical rationalist': s/he believes in an other- or this-worldly ethical order. The second case includes the syndicalist and the pacifist, but also the manifold invocations of natural law legitimating revolt against existing rule without appealing to religious norms or revelation (1978: 867). This case, which secularization makes increasingly relevant, is however problematic to account for in terms of disregard for consequences. The assumption is that an ethical order is immanent to this world, and it can be established or restored despite the latter's current irrationality. Yet, if such order could be affirmed by applying consequential reasoning, the actor would take this route (the ethical agent, qua rational agent, cannot dodge the problem of the relationship between means and ends, Weber says) and the ethic of ultimate ends would be integrated in the ethic of responsibility. Carrying out action 'for its own sake', then, means that such order, while grasped, remains inaccessible through such reasoning. In this case following the principle is the only rational way to proceed. Indeed, even an apparently pointless testimony may contribute, through unknown pathways, to the actualization of the 'right' state of the world.

In short, at least when other-worldly considerations are ruled out, ${ }^{6}$ disregarding available information when planning action would amount, in Weber's own terms, to irrational behaviour. Exemplary action, therefore, makes sense when such information is unavailable (now and possibly ever). Weber's claim that the more one adheres to a principle the less is s/he concerned with consequences has to be read the other way round: the less the consideration of consequences makes sense (because they cannot be reliably assessed), the more a principle may give a clue to how one is to act. ${ }^{7}$

It is interesting to note that, in the period in which Weber writes his conference, the problem of uncertainty is coming to the forefront of the social sciences. This problem differs from the longdebated question of method, to which Weber had also contributed. The issue is not the lack of monocausal explanations of historical and social processes,${ }^{8}$ but the limits of probabilistic reasoning. The development of statistics had offered a possibility of control of situations where, either for the cognitive limits of the actor or for the indeterministic character of phenomena, the causal chain of events is not univocally determinable. The limits of probabilistic prediction begin to be conceptualized with Keynes's (1921) concept of 'personal probabilities' and Knight's (1921) distinction between risk and uncertainty. In both cases the reference is to situations where, in the impossibility of probabilistic quantification, economic decisions have to turn to personal heuristics. This, however, does not mean 
that the actor has to be considered irrational. Rather, the ultimate end (profit) is pursued by relying not only on calculative rationality but also, and sometimes to a decisive extent, on normative assumptions concerning the situation and its possible developments.

The theme of rational decision under uncertainty has continued to be debated. Consider, for example, a recent assessment of the sociologist Jens Beckert. Starting from the classic model of rational choice he distinguishes two situations. In the first, the actor intentionally departs from maximizing the outcomes. This has nothing to do with uncertainty, but with the actor's purposes. A second situation is when the actor departs unintentionally from the maximization of outcomes. This happens when 'the complexity of the situation and/or the limited cognitive capacities of information processing' prevents the actor from 'know[ing] unambiguously which means [to] use to achieve this goal' (2002: 43). In this case normative orientations - Beckert talks of 'fictional expectations', defined as 'present imaginaries of future situations' (2013: 222) - intervene to support the choice of the actor, who otherwise would be blocked by an insuperable uncertainty.

As Keynes and Knight before him, therefore, Beckert argues that in situations where no reliable calculations are possible normative orientations guide decisions. On this ground the ethic of ultimate ends is not a relic of premodern societies, but an ever present option faced with crucial limits to predictive capacities. By the same token, no synthesis or integration between the two ethics is possible, unless ultimate ends are reduced to something else, namely conditional value commitments (we have seen this is what Weber's commentators do).

\section{The growing role of the unforeseeable}

Rationalization means expanding cognitive and operational capacities. In this framework there are good reasons for arguing that the ethic of responsibility replaces or (in a defused form) integrates the ethic of ultimate ends. Weber's limitation of responsibility to foreseeable consequences, a scholar contends, may be actually due to the acknowledgment that, with rationalization, they take growing relevance, while the role of 'the genuinely unforeseeable is quite limited' (Satkunanandan, 2014: 174). This, of course, does not mean that such role is irrelevant. In modern legislation the unforeseeable acts as an exonerating clause from responsibility. Think of liability for defective products. If a defect falls within a threshold of 'normality', that is, statistical predictability, then liability applies, even without the need to demonstrate the producer's negligence (so-called 'strict liability'). If the defect is unusual, that is unforeseeable, the exonerating clause applies. This is especially relevant to a society organizationally complex and pivoting on innovation. The unforeseeable effects of the latter, it is argued, cannot be imputed to innovators, if one is not to discourage progress (see for example European Commission, 1999). As a result, so-called 'development costs' are offloaded onto individuals and groups that are supposed to benefit from innovation. ${ }^{9}$ 
Yet, as Ulrich Beck (1992) has noticed, today the scope of technology has broadened and its complexity increased to the point that a growing number of its effects may be claimed to be unforeseeable. The result is what he calls 'organized irresponsibility' - a systematic exoneration from liability. To address this issue one finds little help in the Weberian literature on the two ethics. Also O'Donovan, who extends responsibility for decisions beyond their 'apparent rationality at the time they were taken' (2011: 99), finds unconceivable an extension beyond the threshold of the foreseeable.

Consider, then, what can be seen as a (weakly) institutionalized reply to organized irresponsibility: the precautionary principle. The idea is that the lack of conclusive data about potential threats cannot lead to postpone measures capable of preventing major or irreversible damages to the environment, health or the physical and psychical integrity of people. Entering soft and hard regulation between the 1980s and 1990s, precaution can be seen as an operational translation of Hans Jonas's (1985) 'imperative of responsibility'.10 However, if reliable data are missing, then normative assumptions play a far greater role than in preventive action, for example in deciding about the seriousness of the threat or the proportionality of interventions. This is no surprise: as we have seen, the deeper the uncertainty, the strongest the role of value commitments. However, one may ask whether and to what extent liability for undesired consequences applies to this type of situation. In this regard a contribution of the philosopher Iris Marion Young can be relevant.

For Young the 'liability model' of responsibility looks backward, requiring to reconstruct the causal chain that links an event to preceding ones and the implied actors. Yet, Young asks, what happens with 'structural injustices', that is 'social processes that put persons under a systematic threat of domination or deprivation of the means to develop and exercise their capacities, at the same time as these processes enable others to dominate or have a wide range of opportunities for developing and exercising their capacities' (2006: 114)? Structural injustices concern the distribution of material and symbolic resources and often depend on extended and loose social connections, which make it hard to identify specific liabilities. Let's think for example of global trade. Consumers can hardly be held liable for worker exploitation or hazardous emissions occurring somewhere in the world, along intricate production chains. For Young, however, since they play their own role in the cooperative scheme enabling exploitation and hazard production, they should acknowledge and take up their part of responsibility. Yet, what can one do? How is one to behave? Given the opacity of the causal chain the answer cannot lie in a search for efficient, effective and predictable courses of action, but rather in 'carrying out activities in a morally appropriate way and aiming for certain outcomes' (2006: 119). In other words, if a detailed reconstruction of causal chains is impossible or extremely onerous, one has to base action on one's own commitment to a certain outcome.

Young's forward-looking account of responsibility bears close affinity with an ethic of ultimate ends. Consumers that, for example, refuse to buy from sweatshops apply the logic of exemplarity discussed above. They assume that, if they act in a certain way, the desired outcome will in the end be achieved. 
This expectation is not irrational, but neither is it means-ends rational, in the sense of based on foreseeable effects. This even in the case of vast mobilizations: a successful boycott campaign may lead to a stop of production and workers' termination, rather than improved work conditions. One may object that this falls within Weber's remark about the distance between original meaning and final result of political action as a reason for grounding it on principled reasons. Yet, one thing is to acknowledge this without giving up the attempt to identify the foreseeable consequences of action; another is to acknowledge that such an attempt is a lost cause.

The spread of 'ethical' consumerism (Micheletti, 2003) shows how globalization and the ensuing increase in social complexity imply growing recourse to the ethic of ultimate ends. The same happens with precaution, to the extent that the growing scope of technology entails growing limits to the prediction of its effects - there is indeed a connection between pretences of manipulating the world and saliency of the unknown (Wynne, 1992). Late modernity, in short, seems a different place to the one Weber envisaged. Instead of a growing disconnect between increasingly powerful means and the ends they are set to achieve, value commitments seem to impinge ever more on the very conception and selection of means.

\section{Loving the unforeseeable}

In the Weberian literature the unforeseeable has a negative stigma: it hampers rational action. This happens also with precaution and Young's forward-looking responsibility. However, an opposed vision has gained momentum, whereby the unforeseeable ceases to be a problem and may even become an opportunity. As a result, the scope for the ethic of ultimate ends broadens further, compared with the examples already discussed.

The turning point is arguably the 1970s. In these years new descriptive and applicative regards on the biophysical and social world begin to appear. One example is the 'ecology of chaos' or 'disorder' (Holling, 1973; Worster, 1990). New accounts of ecosystems depart from traditional ones in that they find in nature no spontaneous tendency to equilibrium: no progressive biomass stabilization; no diversification of species or movement towards greater cohesiveness in plant and animal communities. Change goes on forever, it is claimed, with no direction or tendency to stability; no cooperation, consistence and holistic organization but rather competition, patchiness, fragmentation. Similarly, in chemistry and physics, attention increasingly focuses on 'dissipative structures', that is, thermodynamically open systems that work in a far-from-equilibrium condition and are characterized by the spontaneous formation of dissymmetry and bifurcations, which produce complex, sometimes chaotic, structures (Prigogine and Stengers, 1979). In cybernetics, the homeostasis theorized by Wiener and von Neumann is first replaced by the notion of 'autopoietic systems', with their feedback loops, then by the idea of systemic emergence, as underlying research on artificial intelligence (Hayles, 1999). 
These and other perspectives that have enjoyed growing success, therefore, convey an account of the material world as inherently turbulent and unstable, claiming it is precisely this feature what gives it vitality and dynamism. The policy implications of this account are easy to draw. If stability is the exception rather than the rule, then predictive knowledge based on individuation of regularities loses much of its relevance and appeal. Already in 1972 the nuclear physicist Alvin Weinberg talked of 'trans-science' to express the idea that, in a growing number of cases, classic experimental procedures are impossible to follow. There is no way to prove, for example, that repositories of radioactive waste can stand for hundreds or thousands of years any perturbing event, geological or human (wars, loss of historical memory etc.). Their design and management, therefore, cannot be else than a 'real world' experiment (Krohn and Weyer, 1994), in which each and everyone is involved and the outcomes of which are properly unforeseeable. Similarly, the ecological impacts of agricultural gene technologies cannot be properly assessed via classic experimental procedures. These are fit for detecting the capacity of genetic modifications to fulfil specific goals (crop resistance to adverse climatic conditions or massive use of pesticides; features of fruits such as size, taste and resistance to rotting, etc.) but not for addressing the complex interactions with other organisms occurring in the open environment. Again, what is happening is a real world experiment, in the sense specified above.11

This would be unacceptable according to an ethic of responsibility, yet may make sense in terms of ultimate ends. According to the presently much trumpeted notion of 'research integrity', the 'responsible conduct' of research builds on values such as accuracy and objectivity, which work as criteria for gauging misconduct (Steneck, 2007). Yet, when the unforeseeable plays a crucial role, accuracy and objectivity become, much like Young's ethical consumerism, a matter of aims more than actual performances. For example, if sterility of genetically modified crops extended to non-modified ones, or (as it seems actually happening) super-resistant pests developed as a result of massive use of pesticides with modified crops, this could hardly be stigmatized as lack of accuracy or objectivity as long as sound experimental procedures were applied providing no evidence of problems, in a justificatory framework of alleged major goals ('answer to world hunger' is a favourite trope). These examples show how the scope of the ethic of ultimate ends is increasingly broadening - and with it the category of 'development costs'. Yet, the unforeseeable is still depicted here in negative terms. A further step, then, is conceiving of the unforeseeable as an opportunity. Again, gene technologies offer an example. Systems biology is described as 'an attempt to make sense of the vast amounts of data that have been generated by genome-sequencing projects and other molecular datagenerating exercises' (Calvert and Fujimura, 2009: S46) through application of algorithms, software and mathematical models. Systems biology, moreover, is but one example of the burgeoning application of data mining and processing to generate unforeseen and unforeseeable insights (another major field is security: see Amoore, 2009). Another declension of the 'positive' regard on the unforeseeable comes from geoengineering. 'Solar radiation management' techniques have been 
proposed for reducing the greenhouse effect. The idea is of reflecting solar radiation through launching giant mirrors into space, spraying sulphates into the stratosphere and so on. Given the chaotic character of the atmosphere, however, it is impossible to predict the actual effect, either local or global, of such applications (Macnaghten and Szerszynski, 2013). Their rationale, therefore, cannot build on a traditional notion of control, but rather on the possibility of reacting and adjusting on the spot, moment by moment, to the swerves of the system. The assumption, in other words, is that it is better to 'incite' turbulence rather than wait for its 'unsolicited' manifestation (security, again, offers other examples: see Massumi, 2007). The logic of financial derivatives is similar. One wagers on the variability of an attribute of a given asset (commodity, money, shares etc.), and the prospect for profit grows with the increase in the uncertainty of the performance of such attribute (Bryan and Rafferty, 2014), as amplified by speculation itself. Again, the goal is, so to say, to 'ride' unpredictability. For Holling stability means sclerosis and decline, both in nature and for society. Hence one is to 'embrace uncertainty and unpredictability' (2001: 391). This standpoint is in tune with 'an extensive and immensely influential managerial literature appearing since the early 1980s [...] [which] celebrates uncertainty as the technique of entrepreneurial creativity, [...] the fluid art of the possible' (O'Malley, 2004: 3). From this perspective, uncertainty enhances danger and insecurity but is also 'at the heart of what is positive and constructive' (O'Malley, 2010: 502). Turning upside-down Keynes's and Knight's perspective, proper calculations of risk become the exception, while reasoned bets over unpredictable futures become the rule. What is required is not so much a capacity of calculation, as intuition, foresight, flexibility, experiential judgment, rules of thumb. A recent take on this theme is the case for 'antifragility'. According to Nassim Nicholas Taleb, systems based on knowledge, control and predictability are fragile. The task is to stand randomness, uncertainty, volatility and errors, benefitting from indeterminacy and disorder. To this purpose one has to rely on non-predictive decision making, which allows 'to deal with the unknown, to do things without understanding them and to do them well', since 'we are largely better at doing than we are at thinking' (2012: 4). We should love unknown unknowns, says lyrically Taleb. One may ask where this love for the unforeseeable comes from, being completely at odds with modern rationalization. I cannot attempt a comprehensive reply here. However, it is good to note that the 1970s, when new accounts of reality begin to develop, are the years of stagflation, energy crisis, mounting environmental threats and protest movements, but also of the emersion of the post-Fordist industrial model and the beginning of the 'neoliberal revolution' (Hall, 2011). According to various authors, then, theories of complexity and non-equilibrium, which contained also a libertarian critique of Fordist industrialism and 'commandand-control' regulation, provided a capitalism in crisis with a framework for redirecting socioecological instability towards a new regime of accumulation (Walker and Cooper, 2011; Nelson, 2014). This claim, which builds on the idea of a 'counter-revolutionary' use of notions and demands, such as those coming from protest movements, born with opposite intentions (Virno, 1996; Boltanski and 
Chiapello, 2005), may look, and perhaps is, an oversimplification, not least for the fact that the 'neoliberal revolution' is anything but a consistent process (Brenner et al., 2010). And yet, some tenets of neoliberal theories have become ubiquitous and almost unquestionable, beginning with the idea of crucial limits to prediction and planning faced with social complexity. ${ }^{12}$

Of course, in stressing the growing role of the unforeseeable and the ethic of ultimate ends in present society I am describing a trend, not a generalized situation. For example, synthetic biology works according to a different rationale, compared with systems biology. It adopts a mechanistic conception of the living, imagined as an assembly of parts to be identified, disassembled and reassembled according to purpose. Such broadening room for means-ends rationality should entail a broadening room for the ethic of responsibility. And yet, as noted, with the growth of the capacities of manipulation of materiality, the relevance also grows of the unknown. As a consequence, organized irresponsibility is likely to take growing relevance also in this field, with the innovators' aims increasingly invoked as a justification for undesired outcomes (such as diffusion of crop sterility or super-resistant pests). In other words, the ethic of ultimate ends may expand also where the ethic of responsibility should find an elective terrain of application.

A clue that this is not an unfounded supposition comes from the recent concept and policy framework of 'responsible research and innovation' (RRI). RRI is described as 'a transparent, interactive process by which societal actors and innovators become mutually responsive to each other with a view to the (ethical) acceptability, sustainability and societal desirability of the innovation process and its marketable products' (von Schomberg, 2013: 63). The idea, not new, is to shape innovation before technological 'lock-in' sets in. Novelty lies rather in the proactivity of the approach (the emphasis is on innovation rather than risk) and in the opening of inquiry to 'purpose' questions (rationale, distributive effects, alternatives etc.). RRI seems therefore to strongly foster an ethic of responsibility vis-à-vis innovation. However, from this perspective, its major strength - developing and introducing innovation in society in a collaborative manner - is also its main weakness. In situations of huge difference in agency (big corporations or research centres on one side, fragmented groups of end users or consumer 'representative' organizations on the other), the 'mutual responsiveness' of innovators and stakeholders is likely to result in a major disclaimer - we shared the choice, we share the blame. In other words, it is not difficult to anticipate that RRI is going to legitimise the predominance of the ethic of ultimate ends over the ethic of responsibility much more than it happens with traditional exonerating clauses. This is actually said in plain words in related literature: 'Burdened with imperfect foresight, we take a chance, hoping to be excused from moral blame [let alone legal liability, my adding] if it can be demonstrated we did not have sufficient knowledge of the future consequences of actions at the time: that these could not have been "reasonably foreseen"' (Owen et al., 2013: 28).

\section{Conclusion}


In this paper I have argued that the complex relationship between ethical orientations Weber portrays in his conference resists the interpretation one frequently meets in the critical literature, according to which the ethic of responsibility would have supplanted or integrated the ethic of ultimate ends. This interpretation may be consistent with Weber's contingent purposes and epochal diagnosis, yet downplays how the two ethics imply an opposed relationship with the unforeseeable, which for the one represents a hampering condition, for the other an enabling one. The unforeseeable, moreover, has hardly lost relevance. On the contrary, it has been gaining significance, undermining the claim about the growing dominance of means-ends rationality. The Weberian categories prove invaluable precisely because they can be applied without subscribing to such claim. In fact, not only has the unforeseeable taken a growing role in human affairs, but such role is undergoing an evaluative inversion, being increasingly conceived as an opportunity rather than a problem.

As a result, the ethic of ultimate ends expands its scope. This, however, does not correspond to a return to pre-modern views. In a world where the belief in a cosmic-ethical order plays a lessening role, the unforeseeable rather becomes an exonerating clause of growing power. Said differently, claiming one's good will may authorize and justify any sort of behaviour. It is certainly possible, as Young's 'ethical' consumer does, to broaden or deepen one's sense of obligation towards humans and nonhumans, with ensuing restraint in the pursuit of one's own goals. Yet it is possible also to proceed, with lessening moral, political and legal burdens, with a self-interested and dominative attitude. This is what one detects in a variety of fields, from innovation to finance, from the environment to security, where the unforeseeable is even elicited to be instrumentalized to given purposes. In short, the appeal to ultimate ends seems in many cases to legitimize an enhanced version of the modern expansive hubris - an aspect of rationalization which survives undisturbed.

Then, the strength of the Weberian categories consists not only in their heuristic productivity in a profoundly changed world, but also in their complex relationship. This feature indicates that the game is never definitively over; that the dialectic of means and ends remains open to swerves, inversions and surprises, and that a reason still hostage of dominative dreams can be turned to different directions.

\section{Acknowledgment}

I wish to thank two anonymous reviewers for their insightful comments and critiques to an earlier version of the paper, which prompted me to rework various points of my argument.

\footnotetext{
Notes

${ }^{1}$ For example in the essay on the avalutativity of the social sciences (Weber, 1949a).

${ }^{2}$ For example in the conference on science as a profession (Weber, 1946b).
} 
${ }^{3}$ On a comparable line, Owen e Strong (2004: xlii) talk of an 'existential linkage', rather than theoretical reconciliation, between the two ethics. Also Gane (1997) talks of a 'practical reconciliation' between the two ethics, though, as we have seen, he believes this happens in the framework of Zweckrationalität.

${ }^{4}$ And the Marxist as well (Werskey, 2007).

${ }^{5}$ Think of major R\&D programs, such as the European Horizon 2020, and, within this, of funding lines like the Innovative Medicines Initiative (IMI), where pharmaceutical companies define the topics of the calls for project proposals.

${ }^{6}$ Note, however, that there is a thin line between, and often a mixture of, other-worldly and this-worldly concerns. This results not only from Weber's discussion of asceticism and mysticism, but from analysis of current suicide terrorism. The usual claim is that suicide terrorists are motivated by hope in other-worldly rewards (perhaps mixed with rational choice considerations: high respect within one's community, or contempt in case of retreat). However, investigation shows that a crucial motivating factor resides in a sense of injustice, humiliation and political subservience, against which the need is felt to react (Atran, 2003). Yet, what type of reaction? If power differentials with the adversary hamper the planning of actions in a means-ends rational way, suicidal attacks may make value-rational sense. They offer a testimony to the other-worldly ordering and may contribute, through (humanly) obscure pathways, to the rectification of wrong and the worldwide affirmation of Islam.

${ }^{7}$ Is one leaving in this way the terrain of ethics, entering that of psychology? To answer one should have clear distinctive criteria, which to my knowledge no ethicist or psychologist possesses, and which one can hardly find in Weber, given his account of the problem of Theodicy as based on the lived experience of evil and injustice.

${ }^{8}$ For Weber one has inevitably to select among available data according to research orientations, subsequently investigating the relevance of each chosen element. See the methodological essays of 1904 and 1906 (Weber, $1949 \mathrm{~b}$; 1949c). An outcome of this standpoint is the caution Weber applies in interpreting past events and observed trends, for example in The Protestant Ethic (Weber, 2001) and Bourgeois Democracy in Russia (Weber, 1995).

${ }^{9}$ Countless trials on industrial accidents and 'side effects' focus on ascertaining whether the management had taken safety measures commensurate to the scientific knowledge available at the time of the events in question, on the basis that nothing more could be asked them (Jasanoff, 1997).

${ }^{10}$ Jonas focuses on threats related to increasingly powerful technologies, to address which, he claims, consideration for foreseeable effects is not sufficient. Nothing prevents from applying precaution in addressing natural hazards, such as earthquakes, hurricanes and epidemics.

${ }^{11}$ One may object that this applies also to traditional hybridization techniques. However, these techniques rely on the compatibility of entire organisms, as they result from long evolutionary processes and ecological interactions, which vastly reduce the eventuality of (bad) 'surprises'.

${ }^{12}$ Thinking how, to address stagnation, unemployment and worsening living conditions, governmental elites stick with policies that have proven ineffective (and are arguably at the origin of the problems themselves), in the persuasion that sooner or later these will fulfil their promise of growth and well-being, one might say politics today is by and large driven by an ethic of ultimate ends. In this regard, the difference between liberalism and neoliberalism is important. Liberals seek to regulate less, to avoid that particular values interfere with market exchange, as the spontaneous meeting of individuals provided with own goals and motivations. Neoliberals seek to regulate the conditions for market 
exchange, beginning with people's self-understanding as entrepreneurs of themselves, in order to maximise competition, which is assumed to be the engine of the individual and collective good (Dardot and Laval, 2017).

\section{References}

Amoore L (2009) Algorithmic war: everyday geographies of the war on terror. Antipode 41(1): 49-69.

Atran S (2003) Genesis of Suicide terrorism. Science 299: 1534-39.

Beck U (1992) Risk Society. London: Sage.

Beckert J (2002) Beyond the Market: The Social Foundations of Economic Efficiency. Princeton, NJ:

Princeton University Press.

Beckert J (2013) Imagined futures: Fictional expectations in the economy. Theory and Society 42(3): 219-240.

Boltanski L and Chiapello E (1999) The New Spirit of Capitalism. London: Verso.

Brenner N, Peck J and Theodore N (2010) Variegated neoliberalization: geographies, modalities, pathways. Global Networks 10(2): 182-222.

Brubaker R (1984) The Limits of Rationality. An Essay on the Social and Moral Thought of Max Weber. London: Allen and Unwin.

Bryan D and Rafferty M (2014) Financial derivatives as social policy beyond crisis. Sociology 48(5): 887-903.

Bush V (1945) Science - The Endless Frontier, Washington, DC: Government Printing Office.

Calvert J and Fujimura JH (2009) Calculating life? A sociological perspective on systems biology. EMBO Reports 10 (special issue): S46-S49.

Cherniss J (2016) An ethos of politics between realism and idealism: Max Weber's enigmatic political ethics. Journal of Politics 78(3): 705-718.

Dardot P and Laval C (2017) The New Way of the World: On Neoliberal Society. London: Verso. European Commission (1999) Liability for Defective Products. Green Paper, COM(1999) 396.

Ezrahi Y (1990) The Descent of Icarus. Science and the Transformation of Contemporary Democracy. Cambridge, MA: Harvard University Press.

Gane N (1997) Max Weber on the ethical irrationality of political leadership. Sociology 31(3): 549-564. 
Hall S (2011) The neoliberal revolution. Cultural Studies 25(6): 705-728.

Hayles NK (1999) How We Became Post-Human. Chicago: University of Chicago Press.

Holling CS (1973) Resilience and stability of ecological systems. Annual Review of Ecology and Systematics 4: 1-23.

Holling CS (2001) Understanding the complexity of economic, ecological, and social systems. Ecosystems 4(5): 390-405.

Jasanoff S (1997) Science at the Bar. Cambridge, MA: Harvard University Press.

Jonas H (1985) The Imperative of Responsibility. Chicago: University of Chicago Press.

Keynes JM (1921) A Treatise on Probability. London: MacMillan.

Knight F (1921) Risk, Uncertainty and Profit. Boston, MA: Hart, Schaffner \& Marx.

Krohn W and Weyer J (1994) Society as laboratory: The social risks of experimental research. Science and Public Policy 21(3): 173-183.

Löwith K ([1932]1993) Max Weber and Karl Marx. London: Routledge.

Massumi B (2007) Potential politics and the primacy of preemption. Theory and Event 10(2): n.a.

Macnaghten P and Szerszynski B (2013) Living the global social experiment: an analysis of public discourse on solar radiation management and its implications for governance. Global Environmental Change 23(2): 465-474.

Micheletti M (2003) Political Virtue and Shopping. New York: Palgrave MacMillan.

Nelson S (2014) Beyond the limits to growth: ecology and the neoliberal counterrevolution. Antipode 47(2): 461-480.

O'Donovan N (2011) Causes and consequences: Responsibility in the political thought of Max Weber. Polity 43(1): 84-105.

O’Malley P (2004) Risk, Uncertainty and Governance. London: Glasshouse.

O’Malley P (2010) Resilient subjects: Uncertainty, warfare and liberalism. Economy and Society 3(4): 488-509.

Owen D and Strong T (2004) Introduction: Max Weber's calling to knowledge and action. In: Owen D and Strong T (eds) Max Weber: The Vocation Lectures. Indianapolis: Hackett, pp. ix-lxii.

Owen R, Stilgoe J, Macnaghten P, Gorman M, Fisher E and Guston D (2013) A framework for responsible innovation. In: R. Owen, J. Bessant and M. Heintz (Eds.), Responsible Innovation. Chichester: Wiley, pp. 27-50.

Pellizzoni L (2009) Revolution or passing fashion? Reassessing the precautionary principle. International Journal of Risk Assessment and Management 12(1): 14-34.

Prigogine I and Stengers I (1979) La Nouvelle Alliance. Métamorphose de la Science. Paris: Gallimard. 
Rosenberg MM (2016) Review essay: putting Max Weber to use. Journal of Classical Sociology 16(3) 297-304.

Sahni I-P (2001) 'The will to act': an analysis of Max Weber's conceptualization of social action and political ethics in the light of Goethe's fiction'. Sociology 35(2): 421-39.

Satkunanandan S (2014) Max Weber and the ethos of politics beyond calculation. American Political Science Review 108(1): 169-181.

Scaff LA (1989) Fleeing the Iron Cage: Culture, Politics and Modernity in the Thought of Max Weber. Berkeley, CA: University of California Press.

Schluchter W (1987a) The paradox of rationalization: On the relation of ethics and the world. In: Roth G and Schluchter W (eds) Max Weber's Vision of History. Berkeley, CA: University of California Press, pp. 11-64.

Schluchter W (1987b) Value-neutrality and the ethic of responsibility. In: Roth G and Schluchter W (eds) Max Weber's Vision of History. Berkeley, CA: University of California Press, pp. 65-116.

Steneck NH (2007) Introduction to the Responsible Conduct of Research. Washington, DC: US Office of Research Integrity.

Taleb NN (2012) Antifragile. Things that Gain from Disorder. London: Penguin.

Virno P (1996) Do you remember counterrevolution? In: Virno P and Hardt M (eds) Radical Thought in Italy: A Potential Politics. Minneapolis: University of Minnesota Press., pp. 241-259.

Von Schomberg R (2013) A vision of responsible research and innovation. In: Owen R, Bessant J and Heintz M (eds) Responsible Innovation. Chichester: Wiley, pp. 51-74.

Walker J and Cooper M (2011) Genealogies of resilience. From systems ecology to the political economy of crisis adaptation. Security Dialogue 4(2): 143-160.

Weber M. (1946a) Politics as a vocation. In: Gerth H H and Wright Mills C (eds) From Max Weber: Essays in Sociology (pp. 77-128). New York: Oxford University Press.

Weber M (1946b) Science as a vocation. In Gerth H H and Wright Mills C (eds) From Max Weber: Essays in Sociology. New York: Oxford University Press, pp. 129-156.

Weber M (1949a) The meaning of 'ethical neutrality' in sociology and economics. In: Shils EA and Finch HA (eds) Max Weber on the Methodology of the Social Sciences. Glencoe, IL: Free Press, pp. 1-46. Weber M (1949b) 'Objectivity' in social science and social policy. In: Shils EA and Finch HA (eds) Max Weber on the Methodology of the Social Sciences. Glencoe, IL: Free Press, pp. 49-112.

Weber M (1949c) Critical studies in the logic of the cultural sciences. In: Shils EA and Finch HA (eds) Max Weber on the Methodology of the Social Sciences. Glencoe, IL: Free Press, pp. 113-187.

Weber M (1978) Economy and Society. Berkeley, CA: University of California Press. 
Weber M (1995) Bourgeois democracy in Russia. In: Wells G and Baher P (eds) The Russian Revolutions. Cambridge: Polity Press, pp. 41-147.

Weber M (2001) The Protestant Ethic and the Spirit of Capitalism. London: Routledge.

Werskey G (2007) The Marxist critique of capitalist science: a history in three movements. Science as Culture 16(4): 397-461.

Wildavsky A (1979) Speaking Truth to Power: The Art and Craft of Policy Analysis. Boston: Little and Brown.

Worster D (1990) The ecology of order and chaos. Environmental History Review 14(1-2): 1-18.

Wynne B (1992) Uncertainty and environmental learning. Global Environmental Change 6(2): 111-127. Young, IM (2006) Responsibility and global justice: A social connection model. Social Philosophy and Policy 23(1): 102-130.

\section{Author biography}

Luigi Pellizzoni is professor of sociology at the Department of Political Sciences of the University of Pisa, Italy. His interests focus on risk, uncertainty, environmental and technoscientific change, the transformation of governance, and their implications for social theory. Recent publications include the book Ontological Politics in a Disposable World: The New Mastery of Nature (Routledge, 2016), and the co-editorship of Neoliberalism and Technoscience: Critical Assessments (Ashgate, 2012). 